\title{
BMJ Open Vitamin D deficiency in Malaysian adolescents aged 13 years: findings from the Malaysian Health and Adolescents Longitudinal Research Team study (MyHeARTs)
}

\author{
Nabilla Al-Sadat, ${ }^{1,2}$ Hazreen Abdul Majid, ${ }^{1,2}$ Pei Ying Sim, ${ }^{1}$ Tin Tin Su, ${ }^{1,2}$ \\ Maznah Dahlui, ${ }^{1,2}$ Mohd Fadzrel Abu Bakar, ${ }^{1}$ Najat Dzaki, ${ }^{1}$ Saidatul Norbaya, ${ }^{3}$ \\ Liam Murray, ${ }^{4}$ Marie M Cantwell, ${ }^{4}$ Muhammad Yazid Jalaludin, ${ }^{5}$ \\ MyHeART study group ${ }^{1}$
}

To cite: Al-Sadat N, Majid HA, Sim PY, et al. Vitamin $D$ deficiency in Malaysian adolescents aged 13 years: findings from the Malaysian Health and Adolescents Longitudinal Research Team study (MyHeARTs). BMJ Open 2016;6:e10689. doi:10.1136/bmjopen-2015010689

- Prepublication history for this paper is available online. To view these files please visit the journal online (http://dx.doi.org/10.1136/ bmjopen-2015-010689).

Received 30 December 2015 Revised 16 July 2016 Accepted 18 July 2016

CrossMark

For numbered affiliations see end of article.

Correspondence to Dr Nabilla Al-Sadat; nabilla@ummc.edu.my

\section{ABSTRACT}

Objective: To determine the prevalence of vitamin D deficiency (<37.5 nmol/L) among young adolescents in Malaysia and its association with demographic characteristics, anthropometric measures and physical activity.

Design: This is a cross-sectional study among Form 1 (year 7) students from 15 schools selected using a stratified random sampling design. Information regarding sociodemographic characteristics, clinical data and environmental factors was collected and blood samples were taken for total vitamin D. Descriptive and multivariable logistic regression was performed on the data.

Setting: National secondary schools in Peninsular Malaysia.

Participants: 1361 students (mean age $12.9 \pm 0.3$ years) (61.4\% girls) completed the consent forms and participated in this study. Students with a chronic health condition and/or who could not understand the questionnaires due to lack of literacy were excluded. Main outcome measures: Vitamin D status was determined through measurement of sera 25hydroxyvitamin $\mathrm{D}(25(\mathrm{OH}) \mathrm{D})$. Body mass index $(\mathrm{BMI})$ was classified according to International Obesity Task Force (IOTF) criteria. Self-reported physical activity levels were assessed using the validated Malay version of the Physical Activity Questionnaire for Older Children (PAQ-C).

Results: Deficiency in vitamin D was seen in $78.9 \%$ of the participants. The deficiency was significantly higher in girls $(92.6 \%, p<0.001)$, Indian adolescents $(88.6 \%$, $\mathrm{p}<0.001)$ and urban-living adolescents $(88.8 \%, \mathrm{p}<0.001)$. Females (OR=8.98; 95\% $\mathrm{Cl} 6.48$ to 12.45), adolescents with wider waist circumference $(\mathrm{OR}=2.64 ; 95 \% \mathrm{Cl} 1.65$ to 4.25 ) and in urban areas had higher risks (OR=3.57; $95 \%$ Cl 2.54 to 5.02) of being vitamin D deficient.

Conclusions: The study shows a high prevalence of vitamin $\mathrm{D}$ deficiency among young adolescents. Main risk factors are gender, ethnicity, place of residence and obesity.

\section{Strengths and limitations of this study}

First study among a cohort of adolescents in Malaysia.

- Data from different waves of this Iongitudinal study will provide richer evidence on exposure to risk for vitamin $D$ deficiency among adolescents.

- A major limitation of this report is that there are many other risk factors to vitamin $D$ deficiency such as skin pigmentation, cloud cover, amount of clothing and nutritional intake not reported here, but we have taken further steps in the next wave to resolve those issues.

\section{INTRODUCTION}

Vitamin D (calciferol) is a group of fat-soluble secosteroid hormones important in calcium and bone metabolism. Lack of vitamin D manifests as rickets in children and degenerative bone diseases in older people. ${ }^{1}$ Other studies have additionally shown a relationship between vitamin D deficiency and increased risks of developing chronic illnesses, such as type 1 diabetes and cancer ${ }^{2}$ as well as cardiovascular diseases ${ }^{3}$ in adults. Chowdhury et $a t^{4}$ in their meta-analysis revealed a potentially deleterious role of low vitamin D in all-cause and cause-specific mortality in primary and secondary prevention cohorts. This finding is of significant public health importance, as the gradual decline in circulating 25-hydroxyvitamin D $(25(\mathrm{OH}) \mathrm{D})$ concentrations reported globally is likely to continue owing to the increase in the proportion of older populations, obesity and lack of adequate sun exposure combined with sunscreen use. The effects of vitamin D inadequacy in adolescents have not been 
investigated as thoroughly, although it is suspected to be associated with early-onset osteomalacia and hypocalcemia in the case where deficiency is extreme. ${ }^{5}$

Adolescence is a period where rapid skeletal growth equates to rapid vitamin D usage. The Ministry of Health Malaysia has suggested a cut-off point of $200 \mathrm{IU}$ per day $(5 \mu \mathrm{g})$ of vitamin $\mathrm{D}$ intake for males and females aged between 13 and 18 years. ${ }^{6}$ Dermal synthesis is the major natural source of vitamin D $(90 \%)$ as very few foods naturally contain vitamin D. Provided that there is sufficient skin exposure to sunlight, enough is synthesised from its precursor molecule 7-dehydrocholesterol to achieve the required daily intake level. ${ }^{7}$ Other factors such as diet, skin colour and clothing also influence the serum concentration of vitamin $\mathrm{D}$ in a person. ${ }^{7-9}$

The prevalence of severe vitamin $\mathrm{D}$ deficiency in adolescents is variable, but it is considerably high in many countries, especially in the Middle East and Southeast Asia. $^{2} 7$ Comparatively, Malaysia has reported a better vitamin $\mathrm{D}$ status than other countries ${ }^{2}$ due to its location near the equator. Despite this, studies involving selected groups have indicated the presence of vitamin D deficiency within the population. ${ }^{8}$ This is an unexpected outcome given that Malaysia is a tropical country receiving an average of 7-8 hours of intense sunlight daily; far surpassing the 6-8 min needed for adequate vitamin D production to occur. ${ }^{10}$ Nonetheless, it is not an isolated finding. A similar pattern of deficiency has been shown among adults, children and infants in India, ${ }^{11}$ which is also a country with abundant sunlight throughout the year.

There has been a significant rise in the incidence of non-communicable diseases (NCDs) in Malaysia in recent years. Malaysia has the highest number of overweight, obese as well as diabetic adults compared with other countries in the region, and the trend is increasingly seen among its adolescents as well. ${ }^{12}$ It is imperative for the future of the country that all risk factors, especially modifiable risk factors such as the lack of vitamin $\mathrm{D}$, be investigated and acted upon. The current lack of data on vitamin D deficiency among adolescents in Malaysia prompted this study, which aims to report on the prevalence of vitamin D deficiency among Malaysian adolescents and its association with certain demographic and risk factors. Such information may aid in developing preventive and intervention strategies to improve vitamin $\mathrm{D}$ status in adolescents and prevent the development of NCDs in adult life.

\section{Methods}

The data were drawn from the first wave of the Malaysian Health and Adolescents Longitudinal Research Team study (MyHeARTs) project, an ongoing prospective cohort study which plans to follow the adolescents until they reach adulthood. The first wave was conducted from March to May 2012, and involved students from 15 randomly selected public secondary schools in central and northern Malaysia (the states of
Perak, Selangor and the Federal Territory of Kuala Lumpur). The study protocol has been published in detail elsewhere. ${ }^{13}$

\section{Study population}

The study population comprised Form 1 (aged 12-13 years) students, that is, in their first year of secondary school (Form 1 is equivalent to year 7 in the British education system). Students in boarding, religious or vernacular schools were excluded as they are not representative of Malaysian public schools, which the majority of students attend. Only students and their parents/guardians who had submitted completed consent forms were recruited into the study.

\section{Study design}

The MyHeARTs study used a multistage stratified sampling design. The first stage involved selecting two out of four educational regions of Peninsular Malaysia based on probability proportionate to the population size. The second stage involved the selection of schools. A complete list of public secondary schools located in the selected region was obtained from the Ministry of Education Malaysia and used as the sampling frame. The schools were classified as urban and rural based on criteria provided by the Department of Statistics Malaysia. Schools from the urban and rural locations were randomly selected using computer-generated random number lists. In total, there were 595 public schools (238 in Perak (northern region) and 315 in Selangor and Wilayah Persekutuan Kuala Lumpur (WPKL) (central region)). Out of the 15 schools randomly selected, 7 were in Perak, 5 in Selangor and 3 in WPKL. In the final stage, all eligible students from the selected schools were invited to participate in the study. Consent forms, together with a detailed information sheet, were distributed through the school authorities.

The exclusion criteria were students with any type of chronic health condition and those who were not able to answer the questionnaires in either English or Malay. Exclusion was made as well for chronic diseases that could affect growth or the metabolism of calcium or vitamin $\mathrm{D}$ (such as calcium metabolism disorders) and malnutrition (defined as a weight/height ratio $<-2 \mathrm{SD}$ ).

\section{Sample size}

Using the formula $\mathrm{n}=\left(\mathrm{z}^{2} \mathrm{pq} / \mathrm{re}^{2}\right) \times$ design effect, and taking the prevalence of smoking among school-based adolescents aged $13-15$ years in Malaysia as $33 \%,{ }^{11}$ the total sample size calculated for this study was 1500 . There were 3177 students from the 15 selected schools, $2694(85 \%)$ of whom were eligible for the study and who received consent forms. Out of 2694 students, 1361 participated in the study giving an overall participation rate of $51 \%$. This response rate varied by place of residence $(66 \%$ in rural schools compared with $42 \%$ in urban schools) and by states (42\% in Selangor, $50 \%$ in WPKL and $61 \%$ in Perak). 


\section{Blood analysis}

Venous blood samples were taken after an overnight fast of at least 10 hours prior to the study visit. Blood samples were collected by a trained phlebotomist and temporarily stored at $4^{\circ} \mathrm{C}$ in a cool box. The samples were sent to a local pathology laboratory that was International Organization for Standardization (ISO) certified for analysis. Approximately $5 \mathrm{ml}$ of the blood collected was analysed for sera vitamin D. Vitamin D status was determined through measurement of $25(\mathrm{OH}) \mathrm{D}$ via electrochemiluminescence immunoassay (ECLIA by Advia Centaur XP) on a Cobas E 411 analyzer. The interassay coefficient of variation (CV) was $3.6 \%$ at $57.0 \mathrm{nmol} / \mathrm{L}(22.8 \mathrm{ng} / \mathrm{mL})$ and $3.0 \%$ at $170.5 \mathrm{nmol} / \mathrm{L}$ $(68.2 \mathrm{ng} / \mathrm{mL})$. The intra-assay $\mathrm{CV}$ was $3.5 \%$ at $57.0 \mathrm{nmol} / \mathrm{L}$ $(22.8 \mathrm{ng} / \mathrm{mL})$ and $2.9 \%$ at $170.5 \mathrm{nmol} / \mathrm{L}(68.2 \mathrm{ng} / \mathrm{mL})$. The measuring range for this kit was $10-250 \mathrm{nmol} / \mathrm{L}$ or 4$100 \mathrm{ng} / \mathrm{mL}$. During the analytical run of vitamin D, two concentrations of controls were run together with the samples to ensure that the results were reliable.

$25(\mathrm{OH}) \mathrm{D}$ concentrations were classified based on the cut-off points suggested, ${ }^{5}<12.5 \mathrm{nmol} / \mathrm{L}=$ severely vitamin $\mathrm{D}$ deficient; $<37.5 \mathrm{nmol} / \mathrm{L}=$ vitamin $\mathrm{D}$ deficient; between 37.5 and $50 \mathrm{nmol} / \mathrm{L}=$ vitamin D insufficient; $\geq 50 \mathrm{nmol} /$ $\mathrm{L}=$ sufficient vitamin $\mathrm{D}$.

\section{Anthropometric measurement}

Height was measured without socks and shoes using a calibrated vertical Seca 217 portable stadiometer (Seca, UK) to the nearest millimetre. Weight was measured with light clothing using a Seca 813 (Seca, UK) digital electronic weighing scale, to the nearest decimal fraction of a kilogram. Body mass index (BMI) was calculated as weight in kilograms divided by the square of height in metres. The BMI z-score for age and gender was calculated using the WHO Anthro Software V.3.2.2 for the Statistical Package for the Social Sciences (SPSS) macro, based on WHO reference 2007 (WHO, Geneva, Switzerland). Body fat percentage was measured using a portable body composition analyzer (Tanita SC 240 MA Portable Body Composition Analyser, Tanita Europe B.V., The Netherlands). Waist circumference (WC) was measured with a non-elastic measuring tape (Seca 201, Seca, UK) that was positioned midway between the lowest rib margin and the iliac crest. Measurement was calculated to the nearest millimetre.

The participants were classified into four categories (obese, overweight, normal and underweight) as established by International Obesity Task Force (IOTF) in the year 2000, based on pooled international data for BMI linked to the adults cut-off values. Central obesity was defined by waist circumference $\geq 90$ th centile as determined by waist circumference centile curves for Malaysian children and adolescents. ${ }^{14}$ The cut-off value used was $83.8 \mathrm{~cm}$ for males and $78.8 \mathrm{~cm}$ for females.

\section{Assessment of physical activity}

Self-reported physical activity levels were assessed using the validated Malay version of the Physical Activity
Questionnaire for Older Children (PAQ-C), which has reported satisfactory internal consistency and acceptable validity. $^{15} 16$ Ten items in the PAQ-C were designed to capture the level of physical activity over the course of the 7 days prior to filling in the questionnaire. The mean self-reported physical activity score was further categorised into low (score $<2.33$ ), moderate $(2.33-3.66$ ) and high (score $>3.66$ ) levels. ${ }^{15} 16$

\section{Demographic characteristics}

The sociodemographic information such as gender, age, ethnic group, the educational status and occupational status of the parents was collected from the self-administered questionnaires.

\section{Ethical approval}

Participation in the study was voluntary and written informed consent for participation in the study was obtained from the students as well as their parents/ guardians.

\section{Statistical analysis}

All data including sociodemographic data, anthropometric measurements and biochemical measurements were analysed using SPSS Statistics for Windows, V.22.0. (IBM Corp, Armonk, New York, USA). Categorical variables (gender, ethnicity, place of residence, body fatness) were described as frequencies and percentages. The associations between categorical data were measured using $\chi^{2}$ statistics. The association between outcome (mean vitamin D) and determinants was assessed using Student's t-test and analysis of variance (ANOVA). For significant results in ANOVA, post hoc tests (Tukey) were performed. Measure of effect (OR) and 95\% CI between potential risk factors and outcome, vitamin D deficiency, were analysed by performing univariable and multivariable logistic regression. All results were interpreted using $\mathrm{p}<0.05$ (two sided) as the criterion for statistical significance.

\section{RESULTS}

A total of 1361 Form 1 students (mean age: 12.9 \pm 0.3 years; $61.4 \%$ females) participated in this study. The sociodemographic characteristics of the participants are presented in table 1 . The majority of the participants were of Malay ethnicity, $80.2 \% \quad(n=1091)$, followed by Chinese $7.7 \%(n=105)$, Indians $7.7 \%(n=105)$ and other ethnic groups $3.0 \% \quad(n=41)$. Students from urban $(53.9 \%, \mathrm{n}=723)$ and rural locations $(46.9 \%, \mathrm{n}=638)$ were equally represented. The prevalence of overweight and obesity in this population was $23.9 \% \quad(n=326)$, whereby $15.4 \%(n=210)$ were overweight and $8.5 \%(n=116)$ were obese. Another $21.0 \%(\mathrm{n}=286)$ was underweight. A total of $63 \%(n=858)$ of the adolescents were classified as having low physical activity, with the remaining $37 \%$ had moderate to high levels of physical activity. 
Table 1 Sociodemographic characteristics, physical activities and vitamin D levels of the adolescents

\begin{tabular}{|c|c|c|c|}
\hline Characteristics/variables & $\begin{array}{l}\text { Total adolescents } \\
\text { n (\%) }\end{array}$ & $\begin{array}{l}\text { Male } \\
\mathrm{n}(\%) \\
\end{array}$ & $\begin{array}{l}\text { Female } \\
\mathrm{n}(\%)\end{array}$ \\
\hline \multicolumn{4}{|l|}{ Ethnicity } \\
\hline Malay & 1091 (80.2) & $420(80.0)$ & $671(80.3)$ \\
\hline Chinese & $105(7.7)$ & $42(8.0)$ & $63(7.5)$ \\
\hline Indians & $105(7.7)$ & $34(6.5)$ & $71(8.5)$ \\
\hline Others & $41(3.0)$ & $17(3.2)$ & $24(2.9)$ \\
\hline \multicolumn{4}{|l|}{ Place of residence } \\
\hline Urban & $723(53.1)$ & $240(45.7)$ & $483(57.8)$ \\
\hline Rural & $638(46.9)$ & $285(54.3)$ & $353(42.2)$ \\
\hline \multicolumn{4}{|l|}{ BMI } \\
\hline Underweight & $286(21.0)$ & $103(19.6)$ & $183(21.9)$ \\
\hline Normal & 738 (54.2) & $282(53.7)$ & $456(54.5)$ \\
\hline Overweight & $210(15.4)$ & $82(15.6)$ & $128(15.3)$ \\
\hline Obese & $116(8.5)$ & $56(10.7)$ & $60(7.2)$ \\
\hline \multicolumn{4}{|l|}{ Physical activity } \\
\hline Active & $858(63.0)$ & $232(44.2)$ & $626(74.9)$ \\
\hline Inactive & $482(35.4)$ & $280(53.3)$ & $202(24.2)$ \\
\hline \multicolumn{4}{|l|}{ Vitamin $D$ levels $(n=1361)$} \\
\hline Severe deficiency $25(\mathrm{OH}) \mathrm{D}<12.5 \mathrm{nmol} / \mathrm{L}$ & $20(1.5)$ & $2(0.4)$ & $18(2.2)$ \\
\hline Deficiency $12.15 \leq 25(\mathrm{OH}) \mathrm{D}<37.5 \mathrm{nmol} / \mathrm{L}$ & $1053(77.4)$ & $297(56.6)$ & $756(90.4)$ \\
\hline Insufficiency $37.5 \leq 25(\mathrm{OH}) \mathrm{D} \leq 50 \mathrm{nmol} / \mathrm{L}$ & $187(13.7)$ & $135(25.7)$ & $52(6.2)$ \\
\hline Sufficient $25(\mathrm{OH}) \mathrm{D}>50 \mathrm{nmol} / \mathrm{L})$ & $101(7.4)$ & $91(17.3)$ & $10(1.2)$ \\
\hline
\end{tabular}

The prevalence of vitamin D deficiency (serum 25 $(\mathrm{OH}) \mathrm{D}$ level, $\leq 37.5 \mathrm{nmol} / \mathrm{L})$ in the total sample was $78.9 \%(\mathrm{n}=1073)$ with $1.5 \% \quad(\mathrm{n}=20)$ severely vitamin $\mathrm{D}$ deficient $(25(\mathrm{OH}) \mathrm{D}$ level, $\leq 12.5 \mathrm{nmol} / \mathrm{L})$. Vitamin D insufficiency $(25(\mathrm{OH}) \mathrm{D}$ level, between 37.5 and $50 \mathrm{nmol} / \mathrm{L})$ was seen in 187 participants $(13.7 \%)$. Only 101 of the participants $(7.4 \%)$ had a sufficient vitamin D level $>50 \mathrm{nmol} / \mathrm{L}$.

There was a statistically significant difference between gender, ethnicity, place of residence, BMI, waist circumference, levels of physical activity and mean vitamin $\mathrm{D}$ as determined by one-way ANOVA (7.677(3.101), $\mathrm{p}<0.001$ ) (table 2). A Tukey post hoc test revealed the mean vitamin $\mathrm{D}$ level among males $(37.4 \pm 1.2 \mathrm{nmol} / \mathrm{L})$ was significantly higher compared with females (24.2 $\pm 0.6 \mathrm{nmol} / \mathrm{L})$. The tests also revealed that the mean vitamin D level among Chinese $(30.8 \pm 1.8 \mathrm{nmol} / \mathrm{L})$ was significantly higher compared with Malays (29.1 $\pm 0.8 \mathrm{nmol} / \mathrm{L})$ and Indians $(26.6 \pm 1.6 \mathrm{nmol} / \mathrm{L})$. Although the mean vitamin D level of the 'other' group of ethnicities was highest at $36.1( \pm 5.0 \mathrm{nmol} / \mathrm{L})$; the result was not tested as the numbers in this group were small $(n=41)$.

The mean serum $25(\mathrm{OH}) \mathrm{D}$ level was lower among adolescents living in urban areas $(25.3 \mathrm{nmol} / \mathrm{L}) \mathrm{com}-$ pared with those residing in a more rural setting $(33.7 \mathrm{nmol} / \mathrm{L})$. All three anthropometric measures (BMI, waist circumference and body fat percentages) showed that those who are obese have a lower mean serum $25(\mathrm{OH}) \mathrm{D}$ level compared with those who were normal in weight and other measures. There were also significant differences in mean serum $25(\mathrm{OH}) \mathrm{D}$ level between adolescents who are physically inactive $(27.6 \mathrm{nmol} / \mathrm{L})$ compared with those who are active $(32.2 \mathrm{nmol} / \mathrm{L})$. Among the parental characteristics, variables such as education and employment of either father or mother did not produce significant differences in vitamin $\mathrm{D}$ concentrations.

Following multivariable analysis, the results (table 3) showed that gender, waist circumference and place of residence had a significant relationship to vitamin $\mathrm{D}$ deficiency. Females were more at risk than males $(\mathrm{OR}=8.98$; 95\% CI 6.5 to 12.4), adolescents in urban areas are more at risk $(\mathrm{OR}=3.5 ; 95 \%$ CI 2.5 to 5.0$)$ than adolescents in rural areas and adolescents with wider waist circumference were more at risk $(\mathrm{OR}=2.64 ; 95 \%$ CI 1.65 to 4.25$)$ than those with normal waist circumference.

\section{DISCUSSION}

This study was conducted on adolescents aged 13 years from rural and urban areas in Malaysia. The majority of the students were of Malay ethnicity, followed by Chinese and Indian. As there were more Malays in this study, the results may not be generalised to the whole population of Malaysia and the urban areas in particular, but they are representative of the Malay and Indian population as well as the population in rural areas.

The study revealed that the prevalence of vitamin $\mathrm{D}$ deficiency among Malaysian adolescents of this age group is high at $78.8 \%$. This shows that 8 out of 10 healthy asymptomatic adolescents in Malaysia are suffering from vitamin D deficiency. A similar study conducted in 2008 among 
Table 2 The vitamin D levels of the adolescents with severe vitamin D deficiency, vitamin D deficiency, insufficiency and sufficiency by demographic characteristics and anthropometric measures

\begin{tabular}{|c|c|c|c|c|c|c|}
\hline Variables & $\begin{array}{l}\text { Severe deficiency } \\
\text { n (\%) }\end{array}$ & $\begin{array}{l}\text { Deficiency } \\
\text { n (\%) }\end{array}$ & $\begin{array}{l}\text { Insufficiency } \\
\text { n (\%) }\end{array}$ & $\begin{array}{l}\text { Sufficiency } \\
\text { n (\%) }\end{array}$ & $\begin{array}{l}\text { Mean vitamin D } \\
\text { (nmol/L) }\end{array}$ & ${ }^{*}$ p Value \\
\hline \multicolumn{7}{|l|}{ Gender } \\
\hline Male & $2(0.4)$ & 297 (56.6) & 135 (25.7) & 91 (17.3) & $37.4 \pm 1.2$ & \multirow[t]{2}{*}{$<0.001$} \\
\hline Female & 18 (2.2) & 756 (90.4) & 52 (6.2) & $10(1.2)$ & $24.2 \pm 0.6$ & \\
\hline \multicolumn{7}{|l|}{ Ethnicity* } \\
\hline Malay & $17(1.6)$ & $840(77.0)$ & 144 (13.2) & $90(8.2)$ & $29.1 \pm 0.8$ & \multirow[t]{4}{*}{0.001} \\
\hline Chinese & $1(1.0)$ & 89 (84.8) & 13 (12.4) & 2 (1.0) & $30.8 \pm 1.8$ & \\
\hline Indian & $2(1.9)$ & 91 (86.7) & $10(9.5)$ & $2(1.9)$ & $26.6 \pm 1.6$ & \\
\hline Others & $0(0)$ & $25(61.0)$ & $9(22.0)$ & $7(17.1)$ & $36.1 \pm 5.0$ & \\
\hline \multicolumn{7}{|l|}{ Place of residence } \\
\hline Urban & $18(2.5)$ & 624 (86.3) & $71(9.8)$ & $10(1.4)$ & $25.3 \pm 0.7$ & \multirow[t]{2}{*}{$<0.001$} \\
\hline Rural & $2(0.3)$ & 429 (67.2) & $116(18.2)$ & $91(14.3)$ & $33.7 \pm 1.1$ & \\
\hline \multicolumn{7}{|l|}{$\mathrm{BMI}^{*}$} \\
\hline Underweight & $3(1.0)$ & 217 (75.9) & 38 (13.3) & $28(9.8)$ & $30.5 \pm 1.5$ & \multirow[t]{4}{*}{0.006} \\
\hline Normal & $10(1.4)$ & $550(74.5)$ & 120 (16.3) & $58(7.9)$ & $29.8 \pm 0.9$ & \\
\hline Overweight & 2 (1.0) & 179 (85.2) & 22 (10.5) & 7 (3.3) & $27.3 \pm 1.4$ & \\
\hline Obese & $4(3.4)$ & 98 (84.5) & $7(6.0)$ & $7(6.0)$ & $26.8 \pm 2.2$ & \\
\hline \multicolumn{7}{|l|}{ Body fat (\%) } \\
\hline Normal & $13(1.45)$ & $667(74.20)$ & 138 (15.35) & $81(9.01)$ & $28.6 \pm 12.5$ & \multirow[t]{2}{*}{0.609} \\
\hline High & $6(1.33)$ & $376(83.56)$ & 49 (10.89) & 19 (4.22) & $26.2 \pm 10.9$ & \\
\hline \multicolumn{7}{|l|}{ Waist circumference $(\mathrm{cm})$} \\
\hline Normal & $15(1.33)$ & $850(74.20)$ & $167(14.84)$ & $93(8.27)$ & $29.8 \pm 13.0$ & \multirow[t]{2}{*}{0.001} \\
\hline High & $4(1.78)$ & 194 (86.22) & 20 (8.89) & 7 (3.11) & $26.9 \pm 10.4$ & \\
\hline \multicolumn{7}{|l|}{ Physical activity } \\
\hline Inactive & $14(1.6)$ & $704(82.1)$ & 97 (11.3) & $43(5.0)$ & $27.6 \pm 0.8$ & \multirow[t]{2}{*}{$<0.001$} \\
\hline Active & $6(1.2)$ & $340(70.5)$ & 79 (16.4) & $57(11.8)$ & $32.2 \pm 1.3$ & \\
\hline \multicolumn{7}{|l|}{ Father } \\
\hline \multicolumn{7}{|l|}{ Education } \\
\hline Form 3 and below & 5 (1.2) & $328(77.0)$ & 55 (12.9) & $38(8.9)$ & $29.7 \pm 1.3$ & \multirow[t]{2}{*}{ NS } \\
\hline Form 4 and above & $15(2.2)$ & $534(78.2)$ & 95 (13.9) & $39(5.7)$ & $28.5 \pm 0.9$ & \\
\hline \multicolumn{7}{|l|}{ Employment } \\
\hline Working full time & $15(1.8)$ & 667 (78.4) & $114(13.4)$ & $55(6.5)$ & $28.6 \pm 0.9$ & \multirow[t]{2}{*}{ NS } \\
\hline Not working full time & $5(2.3)$ & 165 (75.0) & 35 (15.9) & $15(6.8)$ & $29.4 \pm 1.6$ & \\
\hline \multicolumn{7}{|l|}{ Mother } \\
\hline \multicolumn{7}{|l|}{ Education } \\
\hline Form 3 and below & $6(1.4)$ & $345(80.2)$ & $46(10.7)$ & $33(7.7)$ & $29.3 \pm 1.2$ & \multirow[t]{2}{*}{ NS } \\
\hline Form 4 and above & $14(1.9)$ & 559 (76.9) & 109 (15.0) & $45(6.2)$ & $28.6 \pm 0.9$ & \\
\hline \multicolumn{7}{|l|}{ Employment } \\
\hline Working full time/part-time & $8(1.2)$ & $541(78.7)$ & $91(13.2)$ & $47(6.8)$ & $29.0 \pm 1.0$ & \multirow[t]{2}{*}{ NS } \\
\hline Housewives/not working & $12(2.6)$ & $357(76.8)$ & $65(14.0)$ & $31(6.7)$ & $28.7 \pm 1.1$ & \\
\hline
\end{tabular}

Means are presented with SDs.

* $p$ Values were obtained from ANOVA with Tukey's multiple post hoc testing. $p$ Values are used to compare means. Cut-off points: body fat (normal: boy <22\%, girl <29\%; high: boy $\geq 22 \%$, girl $\geq 29 \%$ ), waist circumference (cm) (normal: boy <83.8, girl <78.8; high: boy $\geq 83.8$, girl $\geq 83.8$ ). ANOVA, analysis of variance; BMI, body mass index; NS, not significant.

primary school children (aged 7-12 years) also showed a high prevalence of vitamin D deficiency $(<50 \mathrm{nmol} / \mathrm{L})$ at $35.3 \% .8$ Another nationally representative study among younger children (aged 8-12 years) in 2013 also revealed that almost half the children $(47.5 \%)$ had vitamin D insufficiency. ${ }^{17}$ Interestingly, studies involving the older population of Malaysia also revealed similar results. In a study among postmenopausal women aged 50-65 years in 2004, the prevalence of vitamin $\mathrm{D}$ deficiency $(<50 \mathrm{mmol} / \mathrm{L})$ among Malay women was $73.3 \%$ and $12.2 \%$ was among Chinese women. ${ }^{18}$ Moy and Bulgiba ${ }^{19}$ found the prevalence of vitamin D deficiency $(<50 \mathrm{nmol} / \mathrm{L})$ among a convenience sample of Malay employees (mean age around 48.5 years (SD 5.2 years) ) in one public university to be $87 \%$ in females and $41 \%$ in males. Green et al found similar findings among a convenience sample of women of childbearing age.

Vitamin D deficiency (inclusive of those with either deficient or severely deficient sera $25(\mathrm{OH}) \mathrm{D}$ levels) has been reported among adolescents in several countries including India, ${ }^{11}$ China, ${ }^{20}{ }^{21}$ Italy $^{22}{ }^{2}$ Norway $^{23}$ and other European nations. ${ }^{24}$ Comparatively, the prevalence of vitamin D 
Table 3 Univariable and multivariable logistic regression between vitamin D deficiency and selected variables

\begin{tabular}{|c|c|c|c|c|}
\hline Variables & Total N & $\begin{array}{l}\text { Vitamin D deficiency } \\
25(\mathrm{OH}) \mathrm{D} \leq 37.5 \\
\mathrm{n}(\%)\end{array}$ & $\begin{array}{l}\text { Unadjusted OR } \\
(95 \% \mathrm{Cl})\end{array}$ & $\begin{array}{l}\text { Adjusted OR ( } 95 \% \mathrm{Cl}) \text {, } \\
\text { adjusted for multiple variables }\end{array}$ \\
\hline All & 1361 & $1073(78.8)$ & NA & NA \\
\hline \multicolumn{5}{|l|}{ Gender } \\
\hline Male & 525 & $299(57.0)$ & Ref & Ref \\
\hline Female & 836 & 774 (92.6) & $8.62(6.33 \text { to } 11.75)^{\star}$ & $8.98(6.48 \text { to } 12.45)^{\star}$ \\
\hline \multicolumn{5}{|l|}{ Ethnicity } \\
\hline Malay & 1091 & 857 (78.6) & 0.65 (0.38 to 1.14$)$ & 1.24 (0.65 to 2.36$)$ \\
\hline Chinese & 105 & $90(85.7)$ & Ref & Ref \\
\hline Indian & 105 & 93 (88.6) & $1.39(0.62$ to 3.11$)$ & $1.43(0.59$ to 3.48$)$ \\
\hline Others & 41 & $25(61.0)$ & $0.28(0.12$ to 0.64$) \dagger$ & 0.50 (0.19 to 1.32$)$ \\
\hline \multicolumn{5}{|c|}{ Place of residence } \\
\hline Rural & 638 & $431(67.6)$ & Ref & Ref \\
\hline Urban & 723 & $642(88.8)$ & $3.70(2.79 \text { to } 4.91)^{\star}$ & 3.57 (2.54 to 5.02$)$ * \\
\hline \multicolumn{5}{|c|}{ Waist circumference $(\mathrm{cm}) \ddagger$} \\
\hline Normal & 1125 & $850(75.5)$ & Ref & Ref \\
\hline High & 225 & 194 (86.2) & $2.23(1.45 \text { to } 3.44)^{\star}$ & $2.64(1.65 \text { to } 4.25)^{*}$ \\
\hline \multicolumn{5}{|c|}{ Physical activity $\ddagger$} \\
\hline Inactive & 858 & $718(67.5)$ & $1.95(1.49 \text { to } 2.55)^{*}$ & 0.97 (0.69 to 1.34$)$ \\
\hline Active & 482 & $346(32.5)$ & Ref & Ref \\
\hline \multicolumn{5}{|c|}{$\begin{array}{l}\text { Vitamin D deficiency is defined as those severely deficient }(<12.5 \mathrm{nmol} / \mathrm{L}) \text { and those deficient }(12.5-37.5 \mathrm{nmol} / \mathrm{L}) \text { in } 25 \mathrm{OHD} \text {. } \\
\text { *Indicates } \mathrm{p}<0.001 \text {. } \\
\text { tIndicates } \mathrm{p}<0.05 \text { for statistical significance. } \\
\text { fIndicates missing values from the total of } 1361 \text { participants. OR was obtained from simple unadjusted logistic regression. Adjusted OR was } \\
\text { obtained using multivariable logistic regressions adjusted for gender, ethnicity, place of residence, waist circumference and physical activity. } \\
25(\mathrm{OH}) \mathrm{D}, 25 \text {-hydroxyvitamin D; NA, not applicable; Ref, reference. }\end{array}$} \\
\hline
\end{tabular}

deficiency as shown by $78.9 \%$ of the adolescents in our study population is much higher than the vitamin $\mathrm{D}$ deficiency numbers exhibited by adolescents in China $(68.4 \%),{ }^{21}$ despite the research conducted during winter, and in Italy $^{22}$ at $38.7 \%$. There appears to be a paradox here; neither of those countries has as much sunlight exposure as Malaysia, given its geographical location very near to the equator. However, seasonal exposure to sunlight might be a good explanation as to why some countries, as mentioned above, have a better vitamin D level compared with Malaysia. Italy, for example, has a higher exposure to sunlight from May through September, ${ }^{22}$ thus contributes to a better vitamin D level. Impact of seasonal exposure to sunlight and its impact on vitamin D synthesis would require further investigation in order for us to come up with good justification. Furthermore, when adolescents with insufficient levels of $25(\mathrm{OH}) \mathrm{D}$ at $>37.5$ to $<50 \mathrm{nmol} / \mathrm{L}$ were included, the prevalence of hypovitaminosis $\mathrm{D}$ among Malaysian adolescents is at an astonishingly high level of $92.6 \%$. This is a worrying trend as it shows how prevalent vitamin $\mathrm{D}$ deficiency is in the population, which should warrant immediate attention.

However, severe deficiency was reported in only $1.5 \%$ of the adolescents in this study. This is a significantly lower percentage than that reported among Italian adolescents $^{22}$ at $6.4 \%$, but similar to the Norwegian data ${ }^{23}$ at $1.6 \%$. In Asian populations, a study in Beijing showed $40 \%$ of adolescent girls were severely deficient in vitamin $\mathrm{D}$, particularly during the winter season. ${ }^{20}$ Trends of seasonal-dependence of vitamin D deficiency were also found in regions neighbouring China, such as Mongolia $^{25}$ and Iran. ${ }^{26}$

Similar to others' findings, the prevalence of vitamin $\mathrm{D}$ deficiency in our cohort was more severe in girls than boys. It has been shown again and again to be much more prevalent in females of this age range (aged 918 years) then it is among boys of the same age range. ${ }^{1124}$ In this study, girls had higher odds $(\mathrm{OR}=8.98$; 95\% CI 6.48 to 12.45 ) of having vitamin D deficiency compared with boys. Habibesadat et $a l^{26}$ reported similar results of vitamin $\mathrm{D}$ deficiency among adolescents aged 7-18 years old in North Khorasan, Iran where the age-adjusted odds of serum $25(\mathrm{OH}) \mathrm{D}<30 \mathrm{nmol} / \mathrm{L}$ was 21.12 higher in girls compared with boys. Postulations as to why girls are more susceptible to vitamin D deficiency include the more modest dress codes observed by many girls in this region, as well as the habit of avoiding the sun for cosmetic reasons.

The prevalence of vitamin $\mathrm{D}$ deficiency was also shown to be higher among Malaysian adolescents of Indian and Malay ethnicity compared with the Chinese. These findings have been recorded repeatedly in various studies, ${ }^{7} 827$ indicating that there could be a relationship between greater pigmentation and a less than ideal vitamin D status. Production of vitamin D precursors from exposure to UV radiation is inversely correlated with skin melanin density. ${ }^{28}{ }^{29}$ Consistently, our study also saw the darker skinned adolescents of Indian ethnicity displaying the lowest average sera vitamin D concentrations, when compared with their Malay and Chinese 
counterparts. However, further investigations, such as measuring sun exposure and level of skin pigmentation, are needed before validating them as tools for predicting vitamin D levels.

Our study found that vitamin D deficiency was greater in obese adolescents. Other Malaysian studies such as Khor et $a l \mathrm{~s}^{8}$ and Poh et $a l \mathrm{~s}^{17}$ have demonstrated the same findings. A Dutch study among multiethnic children also reported that the prevalence of insufficient vitamin $\mathrm{D}$ was higher among obese non-white children compared with normal-weight white children. ${ }^{30}$

Maintaining vitamin D sera 25(OH)D levels above $50 \mathrm{nmol} / \mathrm{L}$ could enhance bone health, increase bone density in adolescent girls, ${ }^{31}$ and suppress excessive production of parathyroid hormones. ${ }^{32}$ A study among Korean adolescents aged 12-19 years showed positive correlations between adequate vitamin $\mathrm{D}$ and lowered risks of abdominal obesity, obesity and metabolic syndromes. ${ }^{33}$ However, though $\geq 37.5 \mathrm{nmol} / \mathrm{L}$ is generally accepted as a measure of vitamin D sufficiency in adolescents, there may be other confounding variables that could alter the optimal level for this age group; such as an individual's level of physical activity and vitamin D metabolizing capability. Therefore, further studies will be carried out to support these findings by taking such factors into account, in order to establish an optimal vitamin D level for Malaysian adolescents.

As previously mentioned, the production of vitamin D precursors from exposure to UV radiation is inversely correlated with skin melanin density. ${ }^{28} 29$ Other than low exposure to sunshine, low vitamin D levels in children and adolescents could be the result of poor dietary intake, as suggested by previous studies. ${ }^{24} 3435$ It is fortunate that this study has not neglected the diet component. All participants reported their food consumption over a 7-day period to trained dietitians in order to capture comprehensive nutrient consumption. Further analysis of the diet of the participants and other nutritional factors such as calcium intake and parathyroid hormone (PTH) levels to depict any clinical implications of vitamin $\mathrm{D}$ deficiency will be undertaken in the future.

Our results also showed that there is a relationship between low physical activity and vitamin D deficiency, although it is not significant. Moreover, other studies among adolescents ${ }^{20}{ }^{21}$ have shown that outdoor exercise does indeed increase vitamin D levels in sera. It is thus expected that the more physically active you are, the higher the level of vitamin D in your body.

It is interesting to note that there is a significant association between place of residence and vitamin D deficiency. This study revealed that adolescents in urban areas are more at risk of being deficient in vitamin $\mathrm{D}$ $(\mathrm{OR}=3.57 ; 95 \%$ CI 2.54 to 5.02) compared with adolescents in rural areas. This could be due to lack of exposure to the sun caused by lack of involvement in outdoor activities due to environmental pollution or lack of recreational facilities in urban areas.
Although the occupational and educational status of the parents did not produce any significant differences in vitamin D levels among their children in this study, others have shown that vitamin $\mathrm{D}$ levels do differ between the upper and lower working classes. This is most likely due to differences in the quality of the foods that are consumed on a daily basis. As a result, vitamin D deficiency is typically higher among those with lower socioeconomic status (SES). This finding had been described in populations in the USA, ${ }^{36}$ Finland ${ }^{37}$ and India. ${ }^{38}$ One of the limitations of this study is the lack of income data or data that truly measure SES. Thus, classification of the employment and educational level of the parents might not be reflective of the SES of the families. Further studies are needed to determine how SES and other lifestyle factors contribute significantly to vitamin D levels.

The strength of our study is the large sample of participants. To our knowledge, this is the first large crosssectional study in Malaysia to determine the vitamin D level among school-going adolescents. There are limitations to this study. The cross-sectional design cannot capture the cause-effect relationship. The cohort sample are of the same age group, thus do not reflect the whole adolescent population. More than $80 \%$ of the participants were Malays, which does not reflect the racial composition of Malaysian adolescents. However, this study is still of importance since it is one of only a few that have examined vitamin D levels. Our next step will be in MyHeARTs II 2014, where a follow-up of the same participants will be conducted, through which we hope to establish the longitudinal association between lifestyle factors and vitamin D levels.

\section{CONCLUSION}

It is somewhat unexpected that despite the country being close to the equator $\left(2^{\circ} \mathrm{N}\right)$, the population of adolescents has suboptimal vitamin $\mathrm{D}$ status. It is thus imperative to conduct further investigation on why there is such a high prevalence of vitamin D deficiency among otherwise healthy adolescents. With the strong evidence that vitamin $\mathrm{D}$ status is important in the prevention of NCDs in the community, there should be more effort and investment put into carrying out more research into this area and finding effective interventions to reduce the burden of preventable diseases. One of the most effective ways to improve vitamin D status is by increasing outdoor activities. School children can be encouraged to be outdoors during the optimal vitamin $\mathrm{D}$ exposure period (in Malaysia, it is between 10:00 and 14:00). This is in fact an effective and economical way for vitamin D improvement. Another candidate intervention that we suggest is through food fortification and supplementation. Supplementation has been proven $^{24}$ to enhance vitamin D status. As to whether or not food fortification would generate the same data pattern among adolescents would require further and thorough investigation from future research. 
Author affiliations

${ }^{1}$ Faculty of Medicine, Centre for Population Health (CePH), University of Malaya, Kuala Lumpur, Malaysia

${ }^{2}$ Faculty of Medicine, Department of Social and Preventive Medicine, University of Malaya, Kuala Lumpur, Malaysia

${ }^{3}$ Family Health Development Division, Ministry of Health Malaysia, Putrajaya, Malaysia

${ }^{4}$ Centre for Public Health, Queen's University Belfast, Royal Victoria Hospital, Belfast, UK

${ }^{5}$ Faculty of Medicine, Department of Paediatrics, University of Malaya, Kuala Lumpur, Malaysia

Acknowledgements This study was supported by grants from the University of Malaya Research Programme (RP022-14HTM) and the Vice Chancellor Research Grant (UMQUB3D-2011). The postdoctoral research fellow position for this project was jointly funded by the University of Malaya and Queen's University of Belfast. The funders had no role in study design, collection, analysis and interpretation of data, writing of the manuscript, or decision to submit for publication. The authors would like to thank the responsible authorities, principal, teachers, the students and all in the MyHeARTs field team. They are also grateful for the support and guidance provided by the MyHeARTs group members (Dr Nik Rubiah Nik Abdul Rashid and Dr Zarihah Mohd Zain (Ministry of Health, Malaysia), Dr Maizurah Omar (USM), Dr Mohamad Haniki Nik Mohamed (UIA), Dr Rosnah Sutan (UKM), Dr Nahar Mohd Azmi, Dr Maslinor Ismail, Ms Nithiah Thangiah and Associate Professor Dr Karuthan Chinna (University of Malaya)). They would like to acknowledge the reviewers and editors for their most valuable comments and contributions.

Contributors NA-S, HAM, TTS, MD, SN, LM, MMC and MYJ made substantia contributions to the conception or design of the work. NA-S, HAM, SPY and MYJ had a role in the acquisition, analysis and interpretation of data for the work. NA-S, HAM, SPY, MYJ, ND and MFAB drafted and revised the work and all authors gave final approval and agreed to be accountable for all aspects of the work.

Funding This study was supported by grants from the University of Malaya Research Programme (RP022-14HTM) and the Vice Chancellor Research Grant (UMQUB3D-2011).

Competing interests None declared.

Patient consent Obtained.

Ethics approval Medical Ethics Committee, University Malaya Medical Centre (MEC reference number 896.34)

Provenance and peer review Not commissioned; externally peer reviewed.

Data sharing statement All data from the study, published and unpublished, are available to the principal investigators. The data are managed under the Centre for Population Health (CePH), Faculty of Medicine, University of Malaya, 50603 Kuala Lumpur, Malaysia.

Open Access This is an Open Access article distributed in accordance with the Creative Commons Attribution Non Commercial (CC BY-NC 4.0) license which permits others to distribute, remix, adapt, build upon this work noncommercially, and license their derivative works on different terms, provided the original work is properly cited and the use is non-commercial. See: http:// creativecommons.org/licenses/by-nc/4.0/

\section{REFERENCES}

1. Schoenmakers I, Goldberg GR, Prentice A. Abundant sunshine and vitamin D deficiency. Br J Nutr 2008;99:1171-3

2. Holick MF. Vitamin D: a millenium perspective. J Cell Biochem 2003;88:296-307.

3. Wang TJ, Pencina MJ, Booth SL, et al. Vitamin D deficiency and risk of cardiovascular disease. Circulation 2008;117:503-11.

4. Chowdhury R, Kunutsor S, Vitezova A, et al. Vitamin D and risk of cause specific death: systematic review and meta-analysis of observational cohort and randomised intervention studies. $B M J$ 2014;348.

5. Misra M, Pacaud D, Petryk A, et al. Vitamin D deficiency in children and its management: review of current knowledge and recommendations. Pediatrics 2008;122:398-417.
6. Nutrition NCCoFa. Recommended Nutrient Intakes for Malaysia. A Report of the Technical Working Group on Nutritional Guidelines. 2005.

7. Green TJ, Skeaff CM, Rockell JE, et al. Vitamin D status and its association with parathyroid hormone concentrations in women of child-bearing age living in Jakarta and Kuala Lumpur. Eur J Clin Nutr 2008:62:373-8.

8. Khor GL, Chee WS, Shariff ZM, et al. High prevalence of vitamin D insufficiency and its association with BMl-for-age among primary school children in Kuala Lumpur, Malaysia. BMC Public Health 2011;11:95.

9. Zargar $\mathrm{AH}$, Ahmad S, Masoodi SR, et al. Vitamin D status in apparently healthy adults in Kashmir Valley of Indian subcontinent. Postgrad Med J 2007;83:713-16.

10. Pedersen $\mathrm{Jl}$. Vitamin $\mathrm{D}$ requirement and setting recommendation levels_current Nordic view. Nutr Rev 2008;66(Suppl 2):S165-9.

11. Joshi K, Bhatia V. Vitamin D deficiency in a tropical country-treatment and prevention in children. Indian J Pediatr 2014;81:84-9.

12. Mohamud WN, Musa KI, Khir AS, et al. Prevalence of overweight and obesity among adult Malaysians: an update. Asia Pac J Clin Nutr 2011;20:35-41.

13. Hazreen MA, Su TT, Jalaludin MY, et al. An exploratory study on risk factors for chronic non-communicable diseases among adolescents in Malaysia: overview of the Malaysian Health and Adolescents Longitudinal Research Team study (The MyHeART study). BMC Public Health 2014;14(Suppl 3):S6.

14. Poh BK, Jannah AN, Chong LK, et al. Waist circumference percentile curves for Malaysian children and adolescents aged 6.0-16.9 years. Int J Pediatr Obes 2011;6:229-35.

15. Crocker PR, Bailey DA, Faulkner RA, et al. Measuring general levels of physical activity: preliminary evidence for the Physical Activity Questionnaire for Older Children. Med Sci Sports Exerc 1997;29:1344-9.

16. Dan SP, Mohd NM, Zalilah MS. Determination of factors associated with physical activity levels among adolescents attending school in Kuantan, Malaysia. Malays J Nutr 2011;17:175-87.

17. Poh BK, Ng BK, Siti Haslinda MD, et al. Nutritional status and dietary intakes of children aged 6 months to 12 years: findings of the Nutrition Survey of Malaysian Children (SEANUTS Malaysia). Br J Nutr 2013;110(Suppl 3):S21-35.

18. Rahman SA, Chee WS, Yassin Z, et al. Vitamin D status among postmenopausal Malaysian women. Asia Pac J Clin Nutr 2004;13:255-60.

19. Moy FM, Bulgiba A. High prevalence of vitamin D insufficiency and its association with obesity and metabolic syndrome among Malay adults in Kuala Lumpur, Malaysia. BMC Public Health 2011;11:735.

20. Du X, Greenfield H, Fraser DR, et al. Vitamin D deficiency and associated factors in adolescent girls in Beijing. Am J Clin Nutr 2001;74:494-500.

21. Foo LH, Zhang $\mathrm{Q}$, Zhu K et al. Relationship between vitamin $\mathrm{D}$ status, body composition and physical exercise of adolescent girls in Beijing. Osteoporos Int 2009;20:417-25.

22. Marrone $\mathrm{G}$, Rosso I, Moretti R, et al. Is vitamin D status known among children living in Northern Italy? Eur J Nutr 2012;51:143-9.

23. Oberg J, Jorde R, Almas B, et al. Vitamin D deficiency and lifestyle risk factors in a Norwegian adolescent population. Scand J Public Health 2014;42:593-602.

24. González-Gross M, Valtueña J, Breidenassel C, et al. Vitamin D status among adolescents in Europe: the Healthy Lifestyle in Europe by Nutrition in Adolescence study. British Journal of Nutrition 2012;107:755-64.

25. Fraser DR. Vitamin D-deficiency in Asia. J Steroid Biochem Mol Biol 2004;89-90:491-5.

26. Habibesadat S, Ali K, Shabnam JM, et al. Prevalence of vitamin D deficiency and its related factors in children and adolescents living in North Khorasan, Iran. Journal of Pediatric Endocrinology \& Metabolism 2014:27:431-6.

27. Ataie-Jafari $A$, Rahmat $A B$, Abbasi $F$, et al. Vitamin $D$ status and associated factors in recent-onset type 1 diabetic children in Iran J Diabetes Metab Disord 2012;11:12.

28. Clemens TL, Adams JS, Henderson SL, et al. Increased skin pigment reduces the capacity of skin to synthesise vitamin D3. Lancet 1982;1:74-6.

29. Rockell JE, Green TJ, Skeaff CM, et al. Season and ethnicity are determinants of serum 25-hydroxyvitamin D concentrations in New Zealand children aged 5-14 y. J Nutr 2005;135:2602-8.

30. Radhakishun N, van Vliet M, von Rosenstiel I, et al. High prevalence of vitamin D insufficiency/deficiency in Dutch multi-ethnic obese children. Eur J Pediatr 2015;174:183-90.

31. Viljakainen HT, Vaisanen M, Kemi V, et al. Wintertime vitamin D supplementation inhibits seasonal variation of calcitropic hormones 
and maintains bone turnover in healthy men. $J$ Bone Miner Res 2009;24:346-52.

32. Harkness L, Cromer B. Low levels of 25-hydroxy vitamin D are associated with elevated parathyroid hormone in healthy adolescent females. Osteoporos Int 2005;16:109-13.

33. Nam GE, Kim do H, Cho KH, et al. Estimate of a predictive cut-off value for serum 25 -hydroxyvitamin $\mathrm{D}$ reflecting abdominal obesity in Korean adolescents. Nutr Res 2012;32:395-402.

34. Stephens WP, Klimiuk PS, Warrington S. Seasonal changes in serum 25-hydroxyvitamin D concentrations among Asian immigrants. Clin Sci 1982;63:577-80.

35. Cribb VL, Northstone K, Hopkins D, et al. Sources of vitamin D and calcium in the diets of preschool children in the UK and the theoretical effect of food fortification. $J$ Hum Nutr Diet 2015;28:583-92.

36. Weishaar T, Vergili JM. Vitamin D status is a biological determinant of health disparities. J Acad Nutr Diet 2013;113: 643-51.

37. Rasanen M, Kronberg-Kippila C, Ahonen S, et al. Intake of vitamin $D$ by Finnish children aged 3 months to 3 years in relation to sociodemographic factors. Eur $\mathrm{J}$ Clin Nutr 2006;60:1317-22.

38. Puri S, Marwaha RK, Agarwal N, et al. Vitamin D status of apparently healthy schoolgirls from two different socioeconomic strata in Delhi: relation to nutrition and lifestyle. $\mathrm{Br} J$ Nutr 2008;99:876-82. 